Available online at: https://proceeding.researchsynergypress.com/index.php/rsfconferenceseries1

RSF Conference Series: Business, Management and Social Sciences

e-ISSN 2807-5803/ p-ISSN 2807-6699

Volume 1 Number 3 (2021): 411-418

\title{
The Merdeka Belajar Kampus Merdeka (MBKM) Collaboration with BUMDes Sari Dewi, Maguwoharjo, Sleman
}

\author{
Zuhrohtun1, Sucahyo Heriningsih'1, Kunti Sunaryo ${ }^{1}$, Sriyono ${ }^{1}$ \\ 1Economic and Business, UPN “Veteran Yogyakarta, Indonesia
}

\begin{abstract}
One of the implementations of Merdeka Belajar Kampus Merdeka (MBKM) program at UPN "Veteran" Yogyakarta, contained in the Rector's Regulation No. 13 of 2020 concerning the Implementation of MBKM Program at Universitas Pembangunan Nasional "Veteran" Yogyakarta on September 2, 2020, is the program of village project. This article is the result of applied research on the MBKM program of the Accounting Department in Maguwoharjo village, Sleman Regency. MBKM programs are designed with various financial management assistance activities with one of the partners, which is Badan Usaha Milik Desa (BUMDes) in Maguwoharjo by lecturers and an internship program for students as a form of offcampus learning activities, which is the program of village project. The purpose of the village project is to increase the achievement of the Main Performance Indicators (MPI) of Higher Education number 3 (lecturers doing activities outside campus) and MPI number 5 (performance results of lecturers and students are recognized and can be used by the community). The results of this study indicate that for the implementation of MBKM with the Village Project, among others are: 1 . It has been identified early related to the implementation of learning activities outside the campus (in BUMDes), 2. Identified the potential of BUMDes that can be developed in village project of MBKM activities by students, 3 . Identified the equivalent value of student internships participating in the village project.
\end{abstract}

Keywords: Merdeka belajar kampus merdeka (MBKM), Badan Usaha Milik Desa (BUMDes), Collaboration

This is an open access article under the CC-BY-NC license

\section{INTRODUCTION}

Merdeka Belajar Kampus Merdeka (MBKM) is one of the programs of the Ministry of Education and culture in 2020. One form of MBKM activities on campus is that students can take 1-3 semesters of study outside the campus/study program. This MBKM program frees students to take part in learning with many program choices. Such as following the entire learning process in a study program at a university according to the time and learning load, by following the learning process in the study program to fulfill some of the time and learning load, and the rest following the learning process outside the study program.

Accounting Study Program (Prodi) of Faculty of Economy and Business of UPN "Veteran" Yogyakarta has the vision to become a leading accounting study program in the development of science and technology-based on discipline, strife, and creativity in order to support national development. To achieve this vision and the commencement of MBKM policy by UPN "Veteran" Yogyakarta, which is stated in the Rector's Regulation No. 13 of 2020 concerning the Implementation MBKM at UPN "Veteran" Yogyakarta on September 2, 2020, Accounting Study Program plans to carry out several activities to support the implementation of ILIC program in Accounting Study Program.

Implementation of the MBKM program is with the formulation of a curriculum that supports MBKM optimally because it involves partners to achieve learning outcomes in higher education. In its Corresponding author Zuhrohtun, zuhrohtun@upnyk.ac.id DOI: https://doi.org/10.31098/bmss.v1i3.370 
implementation, the university involves external parties in formulating curricula so that the results of their graduates can be accepted in the world of work. There are several programs that have been implemented by UPN "Veteran" Yogyakarta, including student exchange, lecturer exchange, internship, work practice, teaching assistance, research, humanitarian projects, entrepreneurial activities, independent studies/projects, village developing/KKN. The implementation of the MBKM program in the Accounting Study Program is designed with three types of learning activities from 8 forms of MBKM learning activities, which are (1) industrial internships, (2) village projects, and (3) entrepreneurship.

One of the partners to support the MBKM program in the Accounting study program is BUMDes Sari Dewi in Maguwoharjo Village, Sleman Regency. Village empowerment through BUMDes assistance to support MBKM activities, namely the presence of students for six months, can assist program planning at BUMDes, starting from the study of potential, development problems and challenges, setting development priorities, program design, infrastructure design, community empowerment, management of business entities, development supervision, to monitoring and evaluation, experience in the field of development and community empowerment.

It is expected that the UPNVY Accounting Study Program will participate in preparing students as reliable generations, the opportunity to develop fields of knowledge and student interests through the MBKM internship/assistance program at BUMDes. There are several problems, among others, in BUMDes Sari Dewi in Maguwoharjo Village, which was established in 2019, but the financial management is not optimal. This BUMDes has tremendous potential because it has several business units in the form of market management, savings and loan units, and management of cash assets (land) in Maguwoharjo Village. In line with the implementation of the MBKM program, Accounting Study Program will provide financial management assistance for BUMDes by lecturers and student internship programs as a form of a village project program. This will also increase the achievement of University MPI No. 3 and 5. Several activities carried out in the context of implementing the MBKM program include (1) Evaluation of the Accounting Department curriculum by adding MBKM activities (2) developing collaboration between Study Programs and partners in implementing the MBKM program. The accounting study program collaborates with one of the partners, which is BUMDEs Sari Dewi in Maguwoharjo Village, to support the implementation of learning activities through village projects. This can improve the achievement of the Main Performance Indicators (MPI) of University number 3 (lecturers doing activities outside the campus) and MPI number 5 (performance results of lecturers and students are recognized and can be used by the community).

This study aims to develop and formulate a financial management assistance program for BUMDEs Sari Dewi in MaguwoharjoVillage. Develop Standard Operating Procedures (SOP) for the implementation of MBKM learning activities in the form of internship programs and mentoring for BUMDeas in Maguwoharjo. Prepare Assessment Guidelines (Assessment Rubric) for the implementation of MBKM learning activities for apprenticeship programs and mentoring for BUMDes Sari Dewi in Maguwoharjo Village. This research is very useful in a) Helping to optimize the financial management of BUMDes in Maguwoharjo Village, b). Helping optimize the role of lecturers outside the campus through financial management assistance activities for BUMDes of Maguwoharjo Village, c). Supporting one of the implementations of MBKM of Accounting Study Program through a village project for students. 


\section{LITERATURE REVIEW}

\section{Merdeka Belajar Kampus Merdeka (MBKM) Program}

MBKM program is mandated in the Minister of Education and Culture of the Republic of Indonesia No. 3 of 2020, as well as those described in the Free Learning Guidebook-Free Campus published by the Ministry of Education and Culture. There are nine MBKM Programs, namely (1) Student Exchange, (2) Professional Work Practices, (3) Teaching Assistance in Education Units, (4) Research, (5) Humanitarian Projects (6) Entrepreneurial Activities, (7) Study /Independent Projects, (8) Village Development Projects, and (9) National Defense Training.

Independent Learning Activities at Merdeka Campus is a policy that aims to encourage students to master various sciences that are useful for entering the world of work. MBKM provides an opportunity for students to choose the courses they will take. Universities are expected to develop and facilitate the implementation of the Independent Learning program by making academic guidelines. The programs that are implemented should be prepared and mutually agreed upon between universities and partners. The Independent Learning Program can be in the form of a national program that has been prepared by the Ministry or a program prepared by a university registered in the Higher Education Database. The MBKM program gives freedom and autonomy to educational institutions, free from bureaucratization, lecturers are freed from complicated bureaucracy, and students are given the freedom to choose the fields they are interested in. The Independent Campus is a form of learning in higher education that is autonomous and flexible so as to create a learning culture that is innovative, unfettered, and in accordance with the needs of students (Suwandi, 2020).

\section{Badan Usaha Milik Desa (BUMDes)}

Based on Law no. 6 of 2014, Article 87, 88, 89, and 90 states, BUMDes is a business entity wholly or mostly owned by the village through direct participation from village assets that are separated to manage assets, services, and other efforts, for maximum benefit from the village community. A strong and advanced independent village creates a village that is able to meet the needs of its citizens in producing village products/works proudly and the village's ability to meet their needs. In implementing the village independence program, it is not only sufficient to provide financial support to the village, but it is also important to develop the village economy by creating activities that open access to production, distribution, and markets for rural communities to thrive and be sustainable.

Strategic economic growth in this village focuses on utilizing local/village resources to develop handicraft production, agriculture, fisheries, plantations, animal husbandry, small industries, healthy processed foods. Strategic economic growth in the village can support the strengthening of the village economy by developing the business sector with a collective ownership system, in the form of BUMDes, which has been regulated by law. Various business options can be formed and developed by the village government, for example, village electricity, independent energy villages, village markets, clean water, savings and loan institutions, as well as business/business priorities for village economic development.

In accordance with Permendesa PDTT Number 4 of 2015 concerning the Establishment, Arrangement, and Management, and dissolution of BUMDes, the BUMDes management strategy is gradual by considering the development of innovations carried out by BUMDes, including:

a. socialization and learning about BUMDes,

b. implementation of the Village Deliberation with the subject matter of BUMDes,

c. the establishment of BUMDes, which runs a social business (social business) and a rental business (renting), 
d. business feasibility analysis of BUMDes, which is oriented to brokering, holding, social business, financial business and trading, rental business covering technical and technological aspects, aspects of management and human resources, financial aspects, socio-cultural, economic, political, business, and environmental aspects, aspects of legal entities, and aspects of business planning,

e. development of strategic partnership cooperation in the form of inter-Village BUMDes cooperation or collaboration with private parties, socio-economic organizations, and/or donor agencies,

f. business diversification in the form of BUMDes, which is oriented towards financial business (financial business) and joint venture (holding).

\section{MBKM Program Collaborates with Badan Usaha Milik Desa (BUMDes)}

BUMDes program collaborates with BUMDEs aimed at the welfare of rural communities through the development of regional-owned enterprises management. This requires collaboration between BUMDEs, Industry, and the Campus/University MBKM program. MBKM program is ready to support BUMDes and Higher Education programs that collaborate through the MoU. Universities must quickly adapt to the rapid changes that are happening today, and changes must be made, such as wider learning, to realize every potential that exists in this country. Therefore, the collaboration between universities, industry, and villages must be improved through the assistance of BUMDes, to always work together to build the country, starting from mentoring, managing, and increasing the expertise and capacity of BUMDes management to increase natural resources and collaboration can be further optimized and collaboration with universities that have ideas, thoughts, research, and development as well as human resources.

MBKM activities in collaboration with BUMDes can be a liaison between the community and campus, BUMDes and campus, connecting with students and vice versa. BUMDEs and campuses can be packaged in a new platform, namely MBKM, which includes training activities, to encourage, increase the competence of BUMDes, through 5 principle aspects of village funds as a reference for BUMDes funding sources, namely, Humane Aspects, Social Justice, Diversity, Natural Balance and National Interest. What is certain is that MBKM activities in BUMDes can also support the 3 Priority Use of Village Funds that are prioritized for accelerating village Sustainable Development Goals (SDGs), namely National Economic Recovery, National Priority Programs, and Adaptation of New Village Habits.

\section{RESEARCH METHOD}

\section{Types of research}

This institutional research proposal is applied research, where the research design emphasizes the planning, development, and evaluation of the implementation of the Accounting Study Program of MBKM program with a partner, namely BUMDes in Maguwoharjo.

\section{Research Locations and Subjects}

The research was conducted at BUMDes in Maguwoharjo, which is located at Jl. Ringroad Utara no 14, Kembang Maguwoharjo, Kec. Depok, Sleman, Special Region of Yogyakarta. The research subjects cover all business units of BUMDes in Maguwoharjo, which include market management, savings and loan units, and management of cash (land) assets in Maguwoharjo Village. 


\section{Methods and Data Analysis}

The method used in this research is descriptive method and evaluative method. The descriptive method is used in order to conduct an assessment to collect a number of data and facts that exist in BUMDes of Maguwoharjo. Data collection will use documentation and Focused-Grouped Discussion (FGD). Meanwhile, the evaluation method will be used to assess the readiness to implement the internship program for students.

\section{FINDINGS AND DISCUSSION}

\section{Profile of Maguwoharjo Village and the Institutional of BUMDes Sari Dewi}

Maguwoharjo Village is one of the villages located in the Depok District, Sleman Regency, Yogyakarta Special Region (DIY). Maguwoharjo Village can be established by combining 4 (four) old villages, namely Paingan Village, Nayan Village, Tajem Village, and Kembang Village. This village is a strategic location for the entrance to the Yogyakarta area because it has Adisucipto International Airport. Maguwoharjo Village is also the village with the largest area in Depok District, which reaches 992.83 hectares or $15.01 \mathrm{~km} 2$ consisting of rice fields covering an area of 292.36 hectares, settlements, and fields covering an area of 400.82 hectares, plantations covering an area of 78.31 hectares, and area for public facilities are 221.34 hectares.

Maguwoharjo village has potential in agriculture, fishery, plantation, small industry, medium industry, and trade. The potential of Maguwoharjo Village needs to be managed by the government and the community to achieve community welfare through good public services. Based on Maguwoharjo Village Regulation Number 9 of 2019, BUMDes Sari Dewi in Maguwoharjo was officially established with the intention of encouraging all community activities, both those that develop according to local customs or culture, as well as economic activities through government programs that are submitted to be managed by the community.

In carrying out good corporate governance, BUMDes Sari Dewi in Maguwoharjo is managed by an Operations Executive consisting of one Director/Chairman who supervises the Secretary with the assistance of the Human Resources and General Administration Section, the Treasurer with the assistance of the Head of the Accounting Section and the Head of the Finance Section, and the Manager Operations with the assistance of three Heads of Units. All Operational Implementing activities are monitored by the Supervisory Section, for which the Director/Chairman is responsible to the Village Head.

Institutionally, BUMDes Saridewi in Maguwoharjo is a business entity whose entire or most of the capital is owned by the village through direct participation from village assets which are separated to manage assets, services, and other businesses for the greatest welfare of the village community. Broadly speaking, the stakeholders who are very interested in BUMDes Sari Dewi who are an integral part of the implementation of BUMDes in Maguwoharjo Village are (1) Customers (Community), (2) Village Heads, (3) Supervisory Board, (4) Operational Executors, (5) Employees, and (6) Partners.

\section{Potential of BUMDes Saridewi}

The number of cooperative units and savings and loan business groups, totaling nine units with two types of activities managed by cooperatives and established savings and loan business groups, means that BUMDes Sari Dewi in Maguwoharjo must strive to be able to compete and gain the trust of the community. The advantage of BUMDes Sari Dewi in Maguwoharjo that can be considered is that this business entity is supported by the village government so that the level of public trust regarding the legality of the business 
unit can be achieved. Classification of Business Types of BUMDes in accordance with Perdes 9 of $2019 \mathrm{ch}$. 4:

1. BUMDes can run a simple social business that provides public services (serving) to the community by obtaining financial benefits.

2. BUMDes can run a rental business of goods to serve the needs of the Village community and is aimed at obtaining Village Original Income.

3. BUMDes can run a brokerage business that provides services to residents.

4. BUMDes can run a business in the agricultural sector, from the production process of cultivation, post-harvest processing, and sales of production inputs and agricultural crops.

5. BUMDes can run a business that produces and/or trades certain goods to meet the needs of the community or market them on a wider market scale.

6. BUMDes can run a financial business (financial business) that meets the needs of micro-scale businesses run by Village economic entrepreneurs.

7. BUMDes can run a joint business (holding) as the parent of business units developed by the Village community both on a local village scale and in rural areas.

\section{Implementation of MBKM Activities With BUMDes Sari Dewi}

The village project activity is an MBKM activity by including the Thematic Real Work Lecture (KKNT), which can be one of the learning activities outside the campus in the Independent Learning program (MBKM) with a weight of 3 credits. Thematic Real Work Lecture activities are a form of education by providing direct learning experiences for students to stay and live in the community so that students can develop village potential, handle problems and provide solutions to existing problems. MBKM in this village is carried out for six months with a weight equivalent to 20 credits, and this activity is carried out in groups with about ten members or as needed, and members consist of various scientific disciplines. MBKM Accounting Study Program with BUMDes Sari Dewi as partners is expected to hone crossdisciplinary team collaboration, leadership, communication, and partnership soft skills for students. Building a village with implementation in BUMDes Sari Dewi:

a. Some preparations for students who will take part in the MBKM program

Planning with Academic Advisors (DPA); regarding the course program or activity program; study outside the university that will be taken according to their interests; Registering activity programs outside the study program in accordance with the mechanism determined by each study program; Complete the requirements for learning activities outside the study program including participating in the selection if any; Participate in a program of learning activities outside the study program in accordance with the provisions of the existing Academic Guidelines.

b. Some of the preparations for Study Programs in the MBKM program

Facilitating students who will take learning outside the study program and outside the university along with the requirements; Forming an evaluation team to determine the equivalence of courses according to the curriculum in the implementation of Independent Learning program at Independent Campus; Prepare SOPs for the implementation of the Independent Learning of Independent Campus program, which includes the control system, registration process, implementation, monitoring, evaluation, and other necessary matters; Implement collaboration with partners that will be developed by the study program for Independent Learning program at Independent Campus. In addition, the Study Program also identifies the structure and mapping of 
the curriculum as well as re-evaluates the Graduate Learning Outcomes (CPL) and Subject Learning Outcomes (CPMK) in each course; Develop or adapt the curriculum to the ILIC implementation model.

c. The presence of accounting study program students for six months can provide opportunities for students to utilize and apply their knowledge, technology, and skills in collaboration with many stakeholders in the field. Several stakeholders in BUMDes Sari Dewi who assist in field implementation include: Human Resources and General Administration Division, Treasurer assisted by the Head of Accounting and Finance Division Head, and Operations Manager assisted by three Unit Heads. With several activities focused on: increasing the entrepreneurial capacity of the community, MSMEs, and managing BUMDes; Solving social problems by producing a real impact at the end of the activity (e.g., village cooperatives generate more profits).

d. The study program with Academic Advisor determines the equivalence of courses according to the curriculum of the internship program and assigns a team of supervisors as representatives of the lecturers who support the equivalent courses. Assessment of Village Project activities is equivalent to several courses including field studies, Cooperative and MSME Accounting, Cost Management, Tax Management, Internal auditing, Indonesian Economy and Community Service, with a total of 20 credits.

e. Assessment of BUMDes partners towards students includes:

Table 1. Assessment of BUMDes partners

\begin{tabular}{|r|l|l|l|l|l|l|}
\hline No & \multicolumn{1}{|c|}{ Evaluation } & $\begin{array}{l}\text { Very } \\
\text { Deficient } \\
\mathbf{< 2 0}\end{array}$ & $\begin{array}{l}\text { Deficient } \\
\mathbf{( 2 1 - 4 0 )}\end{array}$ & $\begin{array}{l}\text { Fair } \\
\mathbf{( 4 1 -} \\
\mathbf{6 0 )}\end{array}$ & $\begin{array}{l}\text { Good } \\
\mathbf{6 1 -} \\
\mathbf{8 0}\end{array}$ & $\begin{array}{l}\text { Very } \\
\text { Good } \\
>\mathbf{8 1}\end{array}$ \\
\hline 1 & Ethics and discipline & & & & & \\
\hline 2 & $\begin{array}{l}\text { Ability to communicate and } \\
\text { collaborate }\end{array}$ & & & & & \\
\hline 3 & Independency & & & & & \\
\hline 4 & Creativity & & & & & \\
\hline 5 & $\begin{array}{l}\text { Ability to complete work in their } \\
\text { field }\end{array}$ & & & & & \\
\hline 6 & $\begin{array}{l}\text { Ability to identify and solve } \\
\text { problems }\end{array}$ & & & & & \\
\hline
\end{tabular}

The internship partner (BUMDes Sari Dewi) provides a supervisor/mentor/coach who accompanies students/student groups during the internship and is delivered to the study program.

\section{CONCLUSION AND FUTURE RESEARCH}

Merdeka Belajar Kampus Merdeka (MBKM), launched by the Minister of Education and Culture, is a framework to prepare students to become graduates who are strong, competent, professional, and ready to become leaders with a high national spirit. The purpose of MBKM policy is that the program of "right to learn three semesters outside the study program" is to improve the competence of graduates, both soft skills and hard skills, to be more prepared and relevant to the times, prepare graduates in the future who are superior and have a good personality, according to the demands of the business world and the industrial world, as well as the dynamics of society. 
To realize the objectives of MBKM activities for the Accounting Study Program, UPNVY requires the cooperation of various partners, one of which is BUMDes Sari Dewi which can be followed by students. MBKM program requires careful preparation from the side of students, lecturers, and study programs to prepare all the necessary mechanisms in the implementation of MBKM in Cooperation with BUMDes Sari Dewi. There are several obstacles related to the COVID-19 pandemic, so the MBKM mechanism is also made more flexible to adapt to the conditions of social restrictions. For further research, it can be done by describing the comparison of the mechanism and practice of implementing the MBKM program.

\section{REFERENCES}

Anggraeni, M. R. R. S. (2016). Peranan Badan Usaha Milik Desa (ROE) Pada Kesejahteraan Masyarakat Pedesaan Studi Pada ROE Di Gunung Kidul, Yogyakarta. Modus, 28 (2), 155-167.

Caya, M. F. N., \& Rahayu, E. (2019). Dampak ROE Terhadap Kesejahteraan Masyarakat di Desa Aik Batu Buding, Kabupaten Belitung, Propinsi Bangka Belitung. Journal of Social Welfare, 20(1).

Direktorat Jenderal Pendidikan Tinggi Kementerian Pendidikan dan Kebudayaan. Buku Panduan Merdeka Belajar-Lampus Merdeka. Direktorat Jenderal Pendidikan tinggi Kemendikbud RI. Edisi ke satu Cetakan ke-1:2020

Direktorat Jenderal Pendidikan Tinggi Kementerian Pendidikan dan Kebudayaan. Buku Panduan Merdeka Belajar-Kampus Merdeka UPN “Veteran” Yogyakarta, Direktorat Jenderal Pendidikan tinggi Kemendikbud RI. Edisi Revisi: 2021

Kementerian Pendidikan dan Kebudayaan. (2020). Buku Panduan Merdeka Belajar: Kampus Merdeka.

Nizam, 2020. Direktur Jenderal Perguruan Tinggi. Buku Saku Panduan Merdeka Belajar Kampus Merdeka. Direktorat Jenderal Pendidikan Tinggi Kementerian Pendidikan dan Kebudayaan tahun 2020. Edisi ke satu, Cetakan ke-1.

Suwandi, S. (2020). Pengembangan KurMPIlum Program Studi Pendidikan Bahasa (dan Sastra) Indonesia yang Responsif terhadap Kebijakan Merdeka Belajar-Kampus Merdeka dan Kebutuhan Pembelajaran Abad ke-21. Dalam: Prosiding Seminar Daring Nasional: Pengembangan KurMPIlum Merdeka Belajar Program Studi Pendidikan Bahasa Indonesia, 21 Oktober 2020, pp 1-12. https://ejournal.unib.ac.id/index.php/semiba/article/view/13356 